\title{
Assessment of silica content in groundwater of Peninsular Indian region using statistical techniques
}

\author{
Kishan Singh Rawat ${ }^{1^{\star}}$, Sudhir Kumar Singh ${ }^{2}$ and Vinod Kumar Tripathi ${ }^{3}$ \\ ${ }^{1}$ Geo-Informatics, Civil Engineering Department, Graphic Era (Deemed to be University) \\ Dehradun - 248002, Uttrakhand, India. \\ ${ }^{2} \mathrm{~K}$. Banerjee Centre of Atmospheric Ocean Studies, IIDS, Nehru Science Centre, University of Allahabad, \\ Prayagraj-21102 (U.P.), India. \\ ${ }^{3}$ Department of Agricultural Engineering, Institute of Agricultural Sciences, Banaras Hindu University, \\ Varanasi - 221005 (U.P.)
}

Received: 2020-02-20

Accapted: 2020-11-23

Keywords:

Chennai municipality;

silica;

Normalized Difference Dispersal

Index;

statistical techniques

Correspondent email:

ksr.kishan@gmail.com

\begin{abstract}
The groundwater resources from open dug wells are the ultimate and inevitable drinking water source in Chennai municipality. These are of shallow depth of 8 to $10 \mathrm{~m}$ with a static water depth range of 30 to $75 \mathrm{~m}$. This study's objective was to assess silica (in the form of Silicon Dioxide, SiO2) in groundwater and to establish their baseline concentration. Twelve wells were monitored in the study area, in some parameters, namely: Chloride $\left(\mathrm{Cl}^{-}\right)$, Total Dissolved Solids (TDS), $\mathrm{pH}$, Electrical Conductivity (EC), and $\mathrm{SiO}_{2}$. We examined the existing relationship between silica and other measured water quality parameters $(\mathrm{Cl}, \mathrm{pH}$, TDS, and EC) using Spearman correlation matrix analysis in SPSS software and Normalized Difference Dispersal Index (NDDI) in Simplex Numerix software that was applied to identify the hotspots of $\mathrm{SiO}_{2}$. The water $\mathrm{pH}$ ranges from 8.09 to 8.37 (slightly alkaline) with an appreciable amount of TDS (730.50 to 1294.50 $\mathrm{ppm}$ ). The groundwater also contains abundant silica (15.50 to $24.0 \mathrm{ppm}), \mathrm{Cl}^{-}$(106 to $438 \mathrm{ppm}$ ), and EC (759.50 to $1837.50 \mu \mathrm{S} / \mathrm{cm}$ ). Further, a geostatistical tool was used to derive NDDI map of groundwater quality parameters and quantified site-specific variations in parameters, namely $\mathrm{SiO}_{2}, \mathrm{Cl}, \mathrm{pH}$, TDS, and EC values. Average NDDI value enrichment was exhibited by $\mathrm{SiO}_{2}(0.09, \approx 0.1)$ it reflects accretion, while average NDDI values of $\mathrm{Cl}^{-}(-0.09, \approx-0.1)$, EC $(-0.04)$, TDS $(-0.03)$, and $\mathrm{pH}(-0.02)$, it outlined that by dilution in particular groundwater parameter.
\end{abstract}

2020 by the authors. Licensee Indonesian Journal of Geography, Indones

breative Commons

Attribution(CC BY NC) licensehttps://creativecommons.org/licenses/by-nc/4.0/.

\section{Introduction}

Silica ( $\mathrm{Si}$ ) is the most abundant substantial component, being after oxygen. It makes up more than 25 percent of the earth's crust. Si not often occurs in component form; almost all exist as compounds (Krauskopf 1967). The usually known compound of $\mathrm{Si}$ is Silicon Dioxide $\left(\mathrm{SiO}_{2}\right)$, otherwise called silica. The primary source of $\mathrm{Si}$ is also sedimentary rockssandstones, shale, and slate (Krauskopf 1967). Due to the abundance of $\mathrm{Si}$ in the peninsular regions, it has become a major chemical constituent of natural water bodies. According to Hem (1985), the major cause of present Si in natural groundwaters is Si minerals' chemical breakdown in rock and sediments by chemical weathering (Jansen et al., 2010). Seepage (or percolate) of earth's crust components such as Si etc., into drinking water, are a cause of concern. Silica has been identified as an environmental nephrotoxin (Ghahramani 2010). Over decades, epidemiological research documented a strong link between exposure to Si and kidney disease (Stratta et al., 2001, Osorio et al., 1987, Hauglustaine et al., 1980). Humans and animals have also shown that high levels of $\mathrm{SiO}_{2}$ in drinking water cause kidney disease (based on experimental studies, Dobbie and Smith1982).
Conventional and routine analysis of Si not performed for hydrogeochemical studies of groundwater systems, whereas many studies show the water quality evaluation (Adji et al., 2017; Singh et al., 2013; Singh et al., 2015; Nemčić-Jurec et al., 2019; Mohariret al., 2019; Maliqi et al., 2020). Due to this fact that limited works of literature exist on the relationship of silica with parameters, such as water-rock interaction (Marchand et al., 2002, Fournier, 1983), temperature conditions at the time of silica acquisition (Fournier 1983), regional heat flow values (Swanberg and Morgan 1978) and depth to the aquifer. This study is an attempt to highlight the significance of Si analysis in groundwater. Si is generated as a result of chemical breakdown of $\mathrm{Si}$ minerals from rocks (underground rocks) and sediments by chemical weathering process (when groundwater circulating) and therefore, the source of Silica $\left(\mathrm{SiO}_{2}\right)$ in groundwater is almost due to waterrock interaction (Hem, 1985). The concentration of $\mathrm{SiO}_{2}$ in groundwater varies range 1 to $30 \mathrm{ppm}$ is an acceptable limit; the average $17 \mathrm{ppm}$ value has come under good condition (Giggenbach et al., 1985). Marchand et al. (2002) reveal that Si in groundwater increases due to interaction with Si rocks and that the Si content is linked to the residence time of water 
underground. Relatively high Si in groundwater, therefore, implies more water-rock interaction process, which, in turn, may be related to various aquifer factors, such as permeability, lithology, and residence time. In another study, Si contamination is due to distinguish rainfall, short residence time shallow groundwater from longer residence time deeper groundwater (Yousafzai et al., 2010).

In the present study, a geostatistical tool was also used to generating NDDI maps of groundwater quality parameters (Cl, pH, TDS, EC) as suggested by Rawat et al. (2017, 2018a). NDDI mapping is a functional tool for evaluating and comparing spatio-temporal variations in groundwater variables (Rawat et al., 2017, 2018a). Geostatistical mapping techniques have been widely applied in different fields, including water quality in bays (Chehata et al., 2007), watersheds (Todd et al., 2010), soil properties (LopezGranados et al., 2005), precipitation (Nour et al., 2006), river discharges (Sauquet, 2006), air pollution (Wackernagel et al., 2004), river and groundwater quality (Gautam et al. 2020; Singh et al., 2020) and study of lakes (Amin et al., 2013; Singh et al., 2018). Most of these studies focus mainly on spatio-temporal statistics and groundwater quality, and a quantitative comparative appraisal of site-specific dispersion and attenuation of chemical elements sparse (Rawat et al., 2017a, b \& c and 2018a, b\& c, Jacintha et al., 2016; Rawat et al., 2019a and 2019b). However, in the present study, a binary approach was followed using geochemical data and GIS (ArcGIS-10) based output images (Rawat et al., 2018d).

Chennai, the study area, is the capital of Tamil Nadu state of India (Figure. 1). Within the study area, there are two rivers; the Koovam river (in North) and the Adyar river (in South), while the Bay of Bengal Coast is in the East (Saravanan et al., 2018 a \& b). The study area is located between latitude $13^{\circ} 4^{\prime} 55.98^{\prime \prime}$ to $13^{\circ} 0^{\prime} 7.50^{\prime \prime}$ (North) and longitude $80^{\circ} 17^{\prime} 22.37^{\prime \prime}$ to $80^{\circ} 8^{\prime} 42.20^{\prime \prime}$ (East), with the elevation varying between $5 \mathrm{~m}$ above mean sea level (Saravanan et al., 2018 a, b\& c) near the coast to about15 m in the western boundary (Figure. 1a). Geologically, the alluvial deposits rest on the hard rock on the eastern and southern parts (Figure. 1b), contour map (Figure. 1c), and digital elevation map (Figure. 1d) of the study area. The hard rock is mainly Charnockites of the Archaean age (Saravanan et al., 2018 a, b \& c). In the northern and western parts, the alluvium rests over the tertiary and Gondwana groups of rocks (Saravanan et al., 2018 a \& b). The average thickness of alluvium varies from $10 \mathrm{~m}$ along the southern boundary to a maximum of $30 \mathrm{~m}$ in the study area's central and eastern parts (Saravanan et al., 2018 a, b \& c). Shallow open dug wells of depth varying from 8 to $10 \mathrm{~m}$ and borewells in the depth range of 30 to $75 \mathrm{~m}$ are the common groundwater extraction structures in the area (Saravanan et al.,2018 a, b \& c).

\section{Climate and rainfall}

The study area comes under a tropical climate. From April to June, the period is generally hot and from December to February is cool (Saravanan et al., 2018 a, b \& c). The average annual temperature is 24.3 ( $\min$.) to $32.9^{\circ} \mathrm{C}(\max )$. The extreme temperatures recorded are 13.9 and $45^{\circ} \mathrm{C}$ (Saravanan et al., $2018 a, b \& c$ ). The humidity is generally high, and the percentage of humidity ranges between 58 and 84. The study area receives the central part of the rainfall during the northeast monsoon period in October, November, and December (Saravanan et al.,2018 a, b \& c). The southwest monsoon rainfall between June and September is generally erratic, and the summer rains are negligible (Saravanan et al., 2018 a \& b). The average annual rainfall recorded in the Meenambakkam Observatory is $1323.7 \mathrm{~mm}$, and in the Nungambakkam Observatory is $1285.6 \mathrm{~mm}$. Around 60 percent of the annual rainfall is contributed from the northeast monsoon, 30 percent from the southwest monsoon, and the balance of around 10 percent is contributed from winter and summer rainfall (Saravanan et al.,2018 a, b\&c).

\section{Data collection}

A total of 11 (under state government-controlled) open dug well water data was collected from Central Groundwater Board-Chennai (CGWB-C). CGWB-C collected water samples between June and September (regular practice, pre, and post-monsoon). Samples were analyzed for $\mathrm{pH}, \mathrm{EC}$, TDS Cl, and Si by CGWB-C. According to the data set from 1999 to 2003, Si was monitored after CGWB-C did not record in 2003. Also, a survey of a topographic map (scale 1:50,000) was used to prepare the base map.
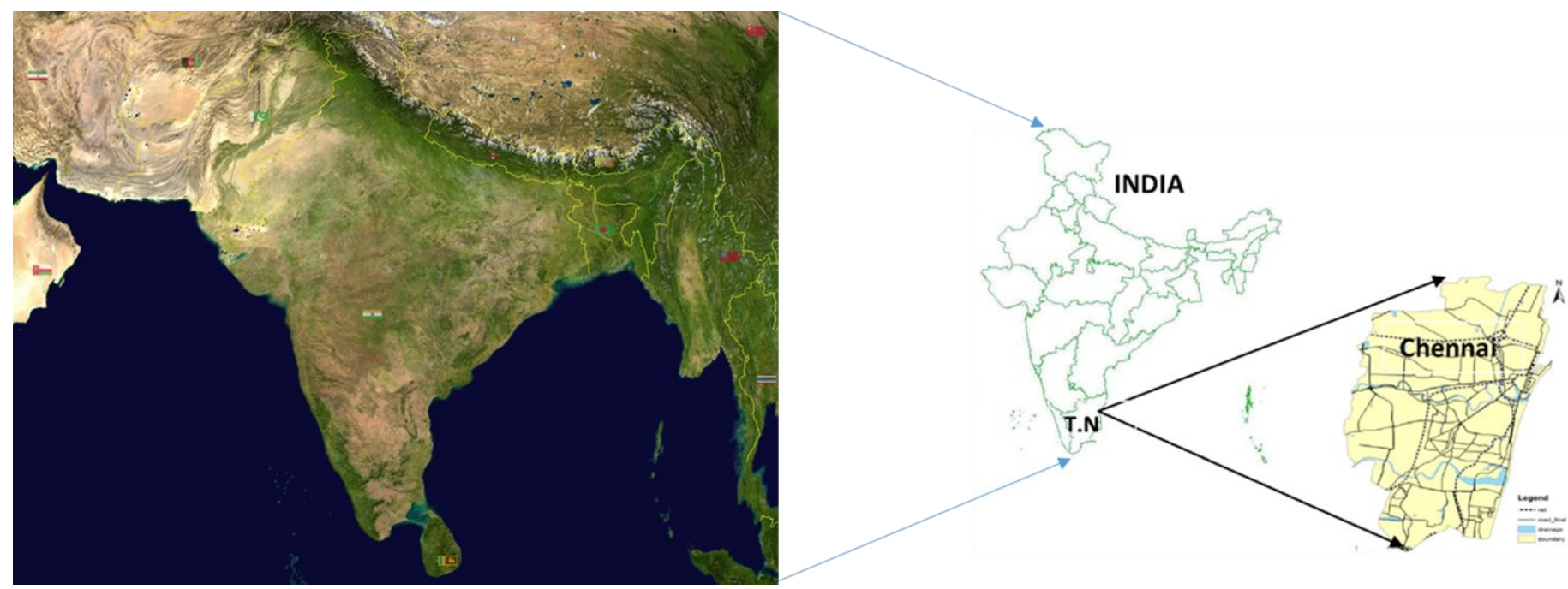

Figure 1a. Location map of the study area 


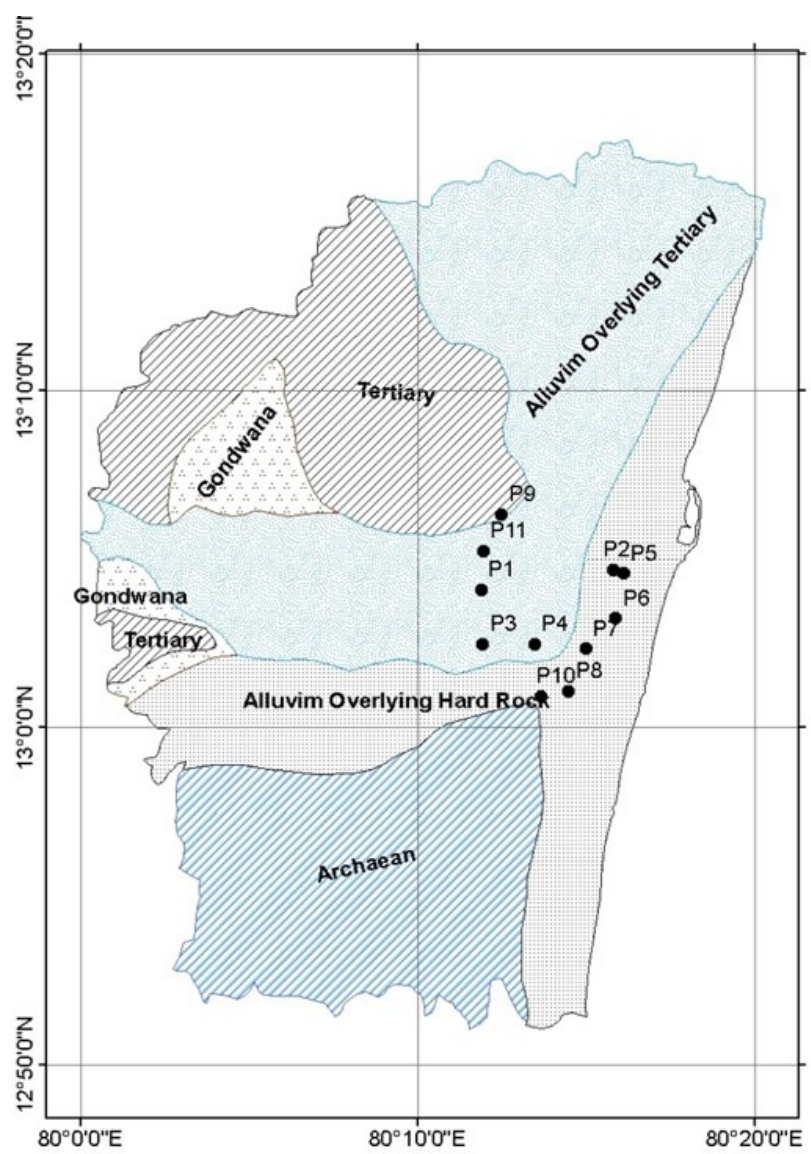

Figure 1b. Geological map of the study area

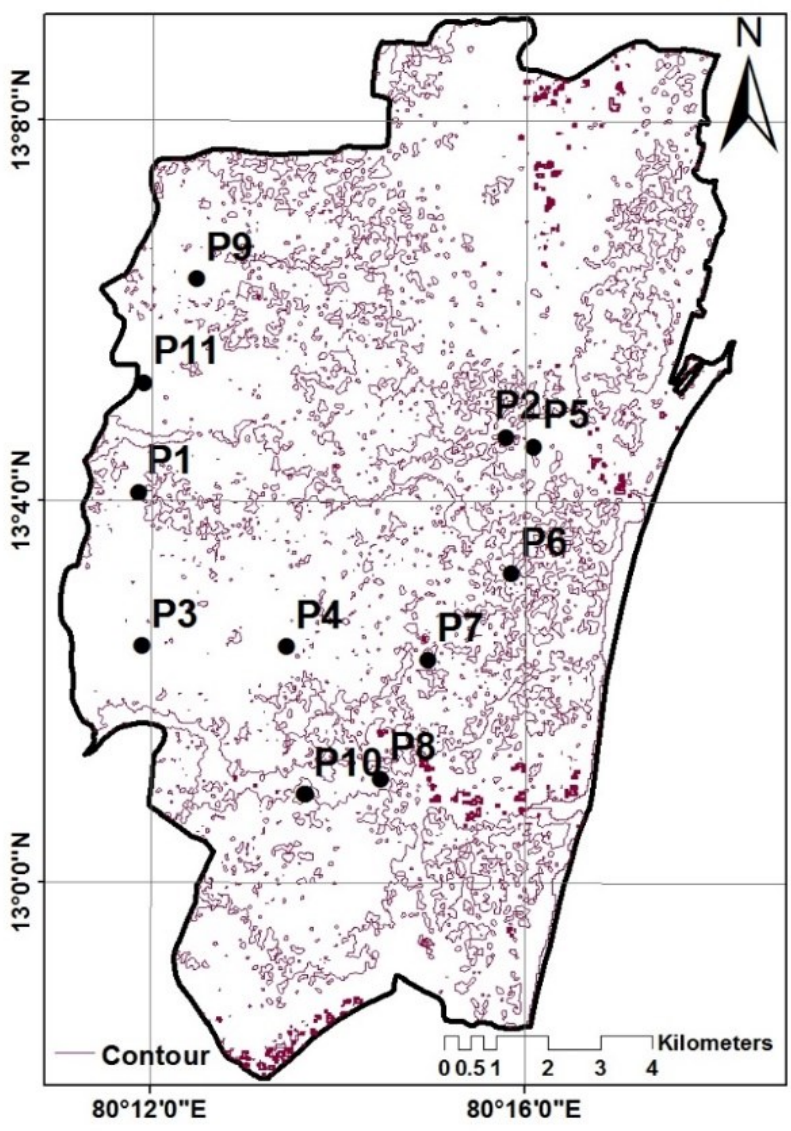

Figure 1c. Contour map of the study area 


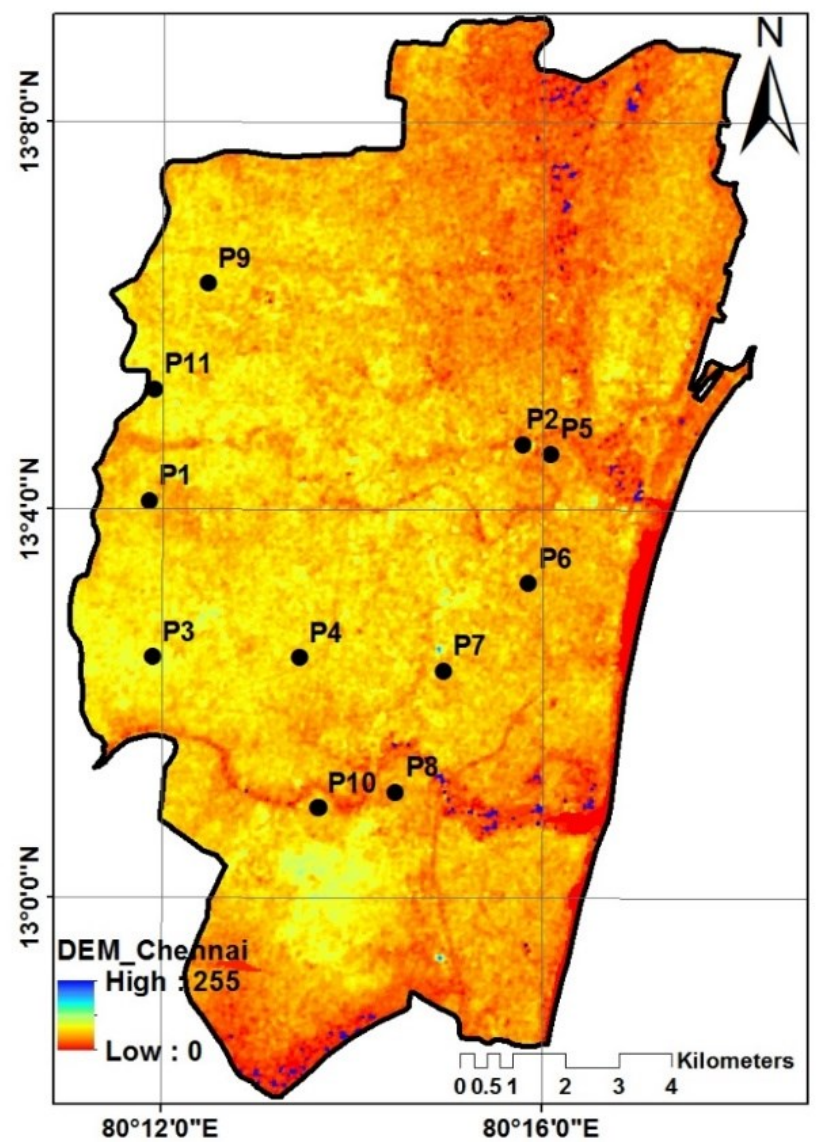

Figure 1d. DEM map of the study area

\section{Normalized Difference Dispersal Index (NDDI)}

The Normalized Difference Dispersal Index (NDDI) is a statistical index and is easy to use. It is the ratio of the concentration of ions in different seasons. It produces a net difference map of chemical constituents in two different seasons (post-pre monsoon) and reveals the spatial and temporal variability of chemical species. The NDDI can be calculated as Eq. (1):

$$
N D D I=\frac{\text { Concentration }(\text { post monsoon }- \text { premonsoon })}{\text { Concentration }(\text { post monsoon }+ \text { premonsoon })}
$$

It ranges between -1 (absolute dilution) and +1 (absolute accretion). The NDDI based maps were prepared using ArcGIS10 (Software) based on NDDI point data.

\section{Correlation analysis}

The correlation coefficient is an essential statistical tool, and its value ranges from -1 (negative correlation) to +1 (positive correlation). The correlation coefficient analysis was performed in Microsoft Office Excel 2007, the correlation matrix of the post, pre-monsoon, and NDDI parameters were also processed. It suggests the tendency of the water quality parameters.

\section{Results and Discussion NDDI mapping}

The NDDI maps conspicuously categorize, demarcate, and quantify the spot-specific enrichment of chemical parameters in the groundwater samples. NDDI values for $\mathrm{pH}$ ranges from +0.01 to -0.14 (Fig. 2), whereas average values were recorded as -0.02 (Fig. 2). It represents the limited but uniform and almost absolute dilution Fig. 3(a). Moreover, one hot spot appeared along with a pink color patch (Royapettah location, Fig. 3(a) and Table 1) with the highest index values as -0.051 to $>0.0$ because this area is closest to the sea. The NDDI image observed that the dilution processes are happening effectively (red color area). The NDDI value of EC ranges from +0.10 to -0.31 (Fig. 2 ), with a median of -0.04 was obtained. The NDDI image Fig. $3(\mathrm{~b})$ of EC illustrates a fair amount of spatial variations in accretion plume (reddish patch along with KK Nagar, T.vNagar, and Velachery location, Table 1) and highly dilution patch (along with Egmore location, Table 1) of pink color. While most of the study area having normal stages (with green color patch). The NDDI map of EC Fig.3(b) was analyzed and illustrated that abundant diffusion of higher and lower pre and postmonsoon seasons values were attributed to the changes. Conversely, average $(-0.03)$ and $\min (-0.31)$ values for TDS was opposing and ranged between +0.01 to -0.31 (Figure. 2), while the median value in the study area reveal that most of the study area come under absolute dilution process for TDS parameter Fig. 3(c). The study area is also showing two pink 
colure patches of enrichment Figure. 3(c). NDDI values of $\mathrm{Cl}$ Fig. 3(d) varied between +0.14 to -0.51 (Fig. 2) and showing abundant diffusion or dilution Fig.3(d). Figure 3(d) revealed that a dilution process appeared with two hot spots (red color patches) along with KK Nagar and Velachery locations (Table $1)$. For $\mathrm{SiO}_{2}$, NDDI values vary between $+0.09(\approx+0.1)$ and $0.07(\approx-0.1)$ with a median of +0.31 (Figure. 2). This represents widespread and almost absolute accrual of average value during pre and post-monsoon seasons because Figure 3 (e) shows most of the study area having red color (accrual) while two small areas of pink color appear in the rage of 0.002 (significantly less dilution process at Koyambedu location, Table 1). Figure 3(e) was clearly established that a particular variation of $\mathrm{SiO}_{2}$ in pre and post monsoons totally changed when the NDDI process was applied. Figure 3(a) to (e) proved that the NDDI process was working well for dilution accrual and absolute accrual studies.

\section{Descriptive statistics}

Tables 2 and 3 tabulated the descriptive statistics for 11 CGWB-C open borewells for the study period of 1999 to 2003 (for post and pre-monsoon). From Table 2 (Fig. 4a), the average value (8.3) of 11 borewells during the post-monsoon (or 4 years post-monsoon) period is under the standard value according to $\mathrm{WHO}-2006(\mathrm{pH}=6.5-8.5)$ while the average maximum $\mathrm{pH}$ value in Koyambedu well (8.37) in four-year post-monsoon is also within WHO-2006 limit. Table 3 (pre-monsoon, Fig. 4 b) average value of 11 wells during pre-monsoon period is excised by the WHO-2006 maximum $\mathrm{pH}$ value of 8.5 for Chintadripet well while other wells are under WHO-2006 limit.

From post-monsoon in Table 2, the minimum and average value of EC for study area are good or low as the permissible limit of WHO-2006 $(300 \mu \mathrm{S} / \mathrm{cm})$ while maximum (Figure. 4a) value (at Villivakkam) of EC is almost

Table 1. NDDI values at a different location

\begin{tabular}{|c|c|c|c|c|c|}
\hline Locations & $\mathrm{SiO}_{2}$ NDDI & $\mathrm{Cl}_{\mathrm{NDDI}}$ & $\mathrm{pH}_{\mathrm{NDDI}}$ & $\mathrm{EC}_{\mathrm{NDDI}}$ & $\mathrm{TDS}_{\mathrm{NDDI}}$ \\
\hline Koyambedu & -0.07 & -0.01 & 0.01 & -0.03 & -0.02 \\
\hline Egmore & 0.19 & -0.41 & -0.01 & -0.05 & -0.05 \\
\hline K.K. Nagar & 0.00 & 0.14 & -0.02 & 0.10 & 0.11 \\
\hline T. Nagar & 0.04 & -0.04 & -0.01 & 0.01 & -0.01 \\
\hline Chintadripet & -0.01 & -0.51 & -0.03 & -0.33 & -0.31 \\
\hline Royapettah & 0.15 & -0.04 & -0.14 & -0.06 & -0.05 \\
\hline Eldams road & 0.09 & -0.15 & -0.01 & -0.15 & -0.12 \\
\hline Kotturpuram & 0.31 & 0.06 & -0.02 & 0.03 & 0.04 \\
\hline Villivakkam & 0.02 & -0.03 & -0.01 & -0.04 & -0.04 \\
\hline Velachery & 0.04 & -0.10 & 0.00 & -0.02 & -0.01 \\
\hline Thirumangalam & 0.04 & -0.06 & -0.01 & -0.02 & -0.02 \\
\hline
\end{tabular}

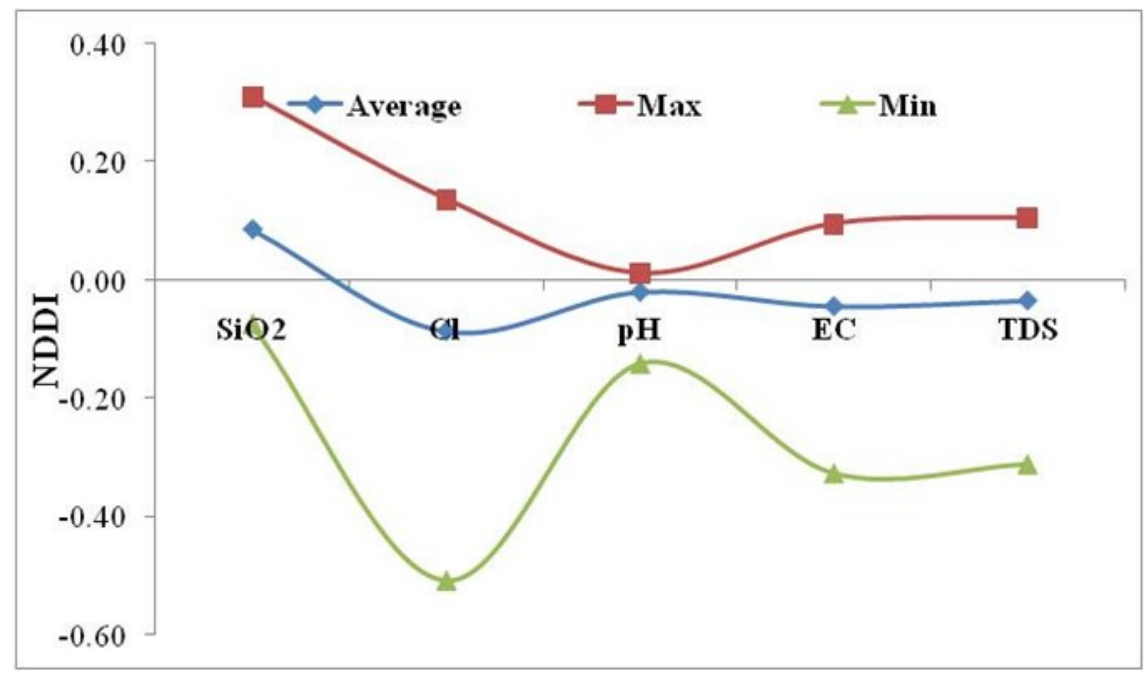

Figure. 2. NDDI conspicuously categorization of water quality parameters at study area. 

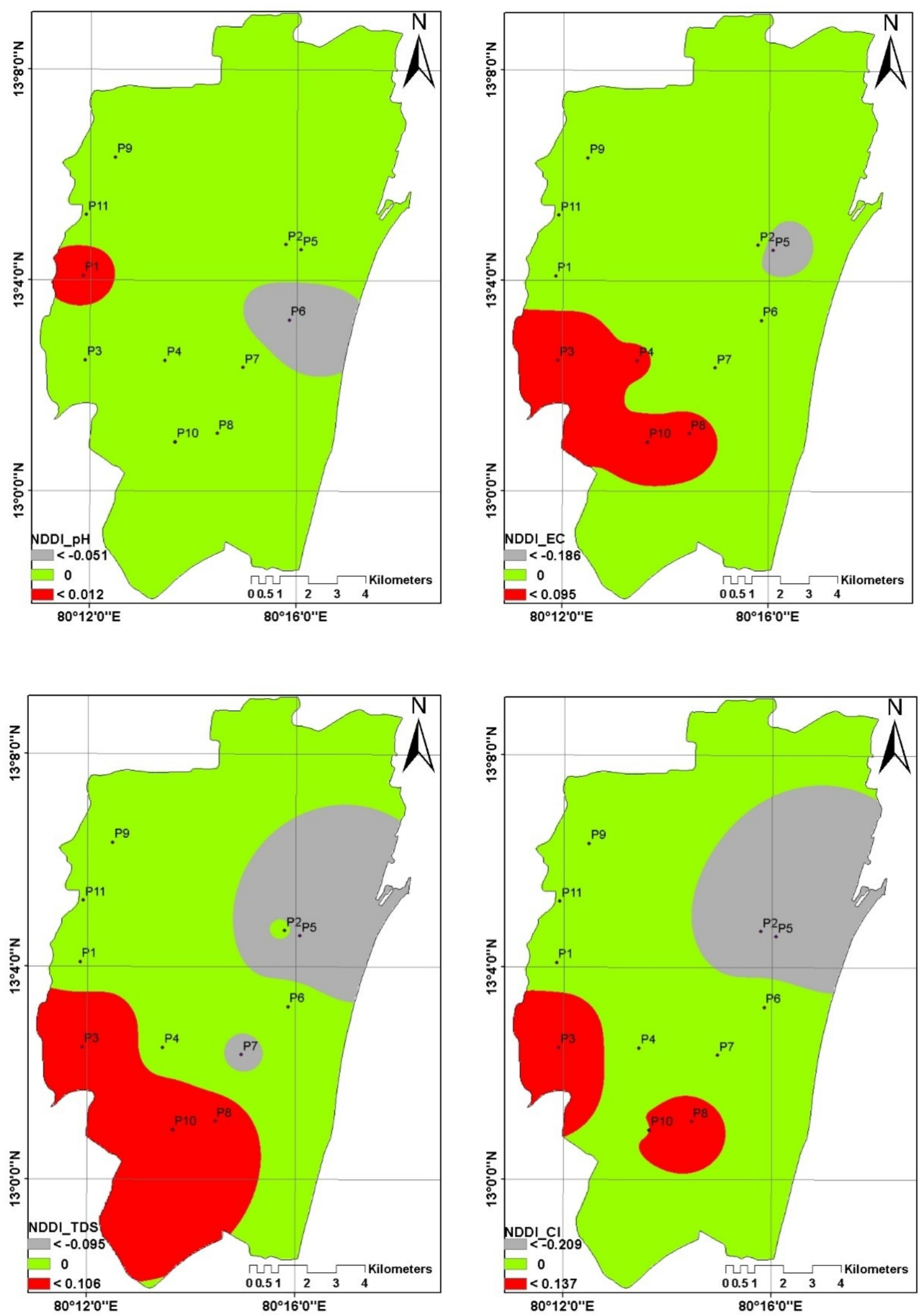


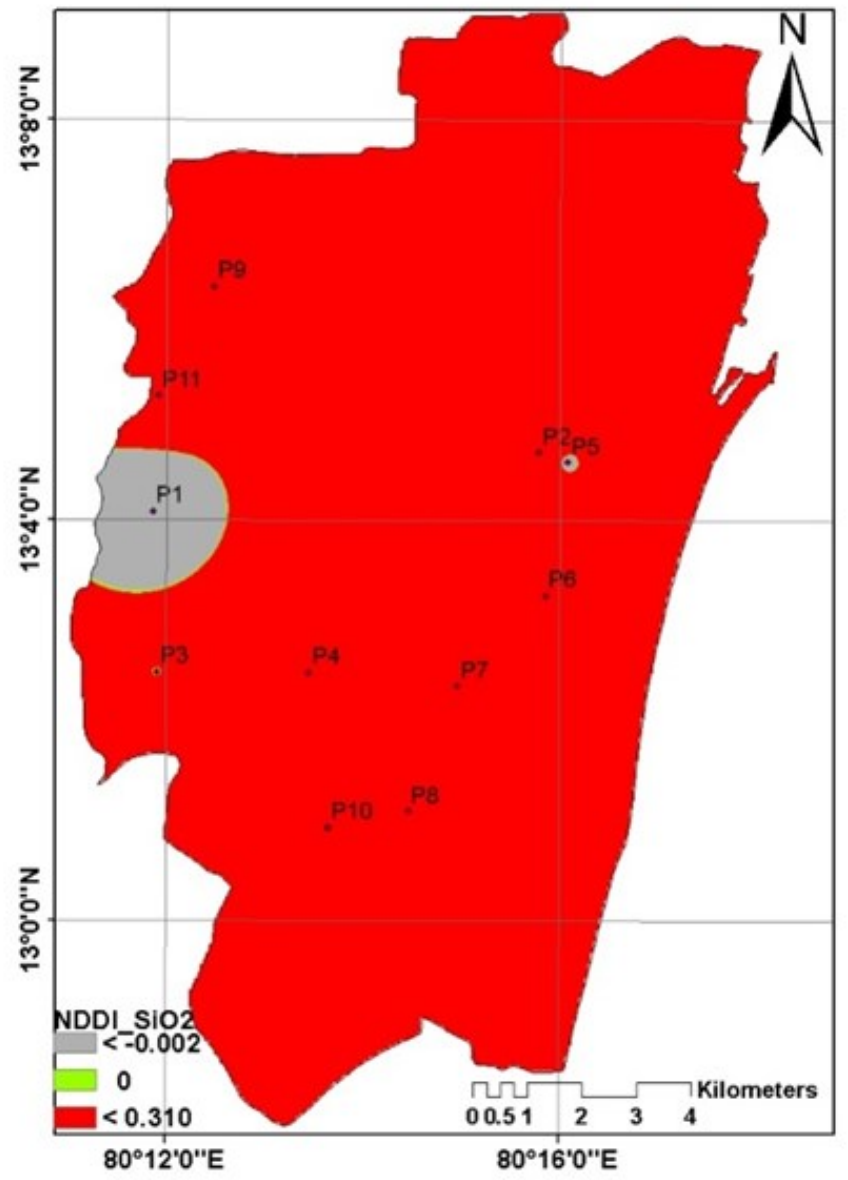

Figure 3.(a) Variation of NDDI value of $\mathrm{pH}$ on surface of study area. (b) Variation of NDDI value of EC on surface of study area. (c) Variation of NDDI value of TDS on surface of study area. (d) Variation of NDDI value of Cl on surface of study area and(e) Variation of NDDI value of $\mathrm{SiO}_{2}$ on surface of study area

1.3 time of standard deviation value for EC as WHO-2006 $(1400 \mu \mathrm{S} / \mathrm{cm})$. Average EC value during pre-monsoon is also low (1.07 time of standard deviation), higher than S.D. value of EC while minimum $(1118 \mu \mathrm{S} / \mathrm{cm})$ at T. Nagar (Jubilee Road)), and maximum (Figure. $4 \mathrm{~b}, 2080 \mu \mathrm{S} / \mathrm{cm}$ or 1.49 time of S.D. of EC at Velachery (Forest Department)) value for 11 CGWB-C open borewells.

Based on WHO-2006 TDS (500 ppm) permissible limit, post-monsoon Table 3 showing TDS min (517ppm at Chintadripet) and average (947.25ppm) value for 11 open borewells are under the permissible limit but the maximum value in the study area during last 4 years post-monsoon (Fig. 4b) is almost 1.36 time (at Velachery (Forest Department)) of WHO-2006 value (1000 ppm). The premonsoon in Table 2 clearly reveals that average minimum values of 11 wells are higher ( 1.41 times) than post-monsoon collation data sets, and it is $730.5 \mathrm{ppm}$ (at T. Nagar, Jubilee Road). However, the average value during pre-monsoon increases (979.88 ppm) compared to post-monsoon.

Table 2 shows that $\mathrm{Cl}$ during the post-monsoon, 4 out of 11 CGWB-C open borewells, namely, Velachery (460 ppm), Kotturpuram (438 ppm), K.K. Nagar (275 ppm) and Villivakkam (259 ppm) in the study area were beyond the $250 \mathrm{ppm}$ (WHO-2006 limit value), while the average value (Fig. 4a) of $\mathrm{Cl}$ for 11 wells for 4 years is found as $230 \mathrm{ppm}$.
Nevertheless, the maximum value of $\mathrm{Cl}$ during the postmonsoon was recorded as $460 \mathrm{ppm}$, which 1.84 times more than the WHO-2006 limit value for $\mathrm{Cl}$. From pre-monsoon (Table 3), it is clear that min (139 ppm atRoyapettah) and max (Figure. 4b, $557 \mathrm{ppm}$ and 2.23 time of standard deviation, at Velachery) value for the study area is changing from post-monsoon, and again max $\mathrm{Cl}$ value for the study area is cross the WHO-2006 limit.

From Table 2, average and min value of $\mathrm{SiO}_{2}$ for the study area during the last study period post-monsoon were 19.95 ppm and 15.5ppm (at Koyambedu) respectively, both values are under the permissible limit as a base on reviews of the literature (because any S.D. value of $\mathrm{Si}$ in drinking water is not prescribed by IS 10500 (Bureau of Indian Standards and WHO) for Si. Meanwhile, during the pre-monsoon, these values have fluctuated. Overall, these values similar to postmonsoon, as shown in Table 3. The average and min values of $\mathrm{SiO}_{2}$ for the study area during the study period of postmonsoon were $17 \mathrm{ppm}$ and $10.5 \mathrm{ppm}$ (at Kotturpuram) respectively, both values are still under the permissible limit.

During the descriptive statistics examining hydrogeochemical parameters for 11 CGWB-C open borewells within the study area, we found EC parameter was dominant as min, max, and average points of view during post and pre-monsoon. 

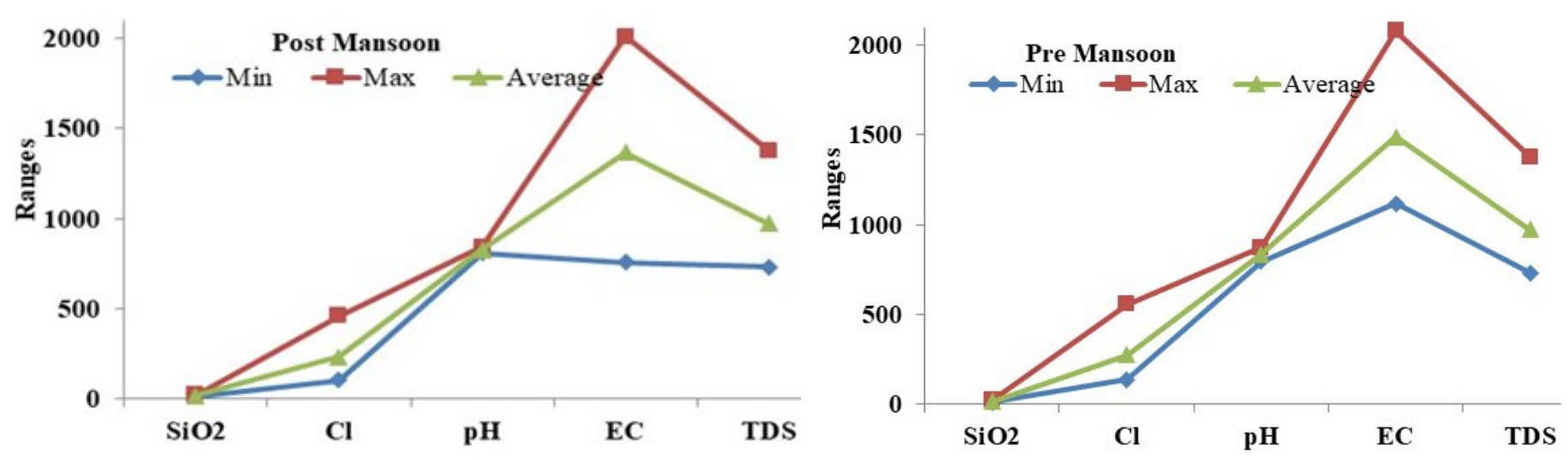

Figure. $4(\mathrm{a}, \mathrm{b})$. The mean content of different water quality constituents limit in the study area

Table 2. Post-monsoon descriptive statistics

\begin{tabular}{|c|c|c|c|c|c|c|c|c|c|c|c|}
\hline \multirow{2}{*}{ Parameters } & \multirow{2}{*}{$\begin{array}{l}\text { Range } \\
\text { Stat. }\end{array}$} & \multirow{2}{*}{$\begin{array}{l}\text { Min. } \\
\text { Stat. }\end{array}$} & \multirow{2}{*}{$\begin{array}{l}\text { Max. } \\
\text { Stat. }\end{array}$} & \multicolumn{2}{|c|}{ Mean } & \multirow{2}{*}{$\frac{\text { Sd. D }}{\text { Stat. }}$} & \multirow{2}{*}{$\frac{\text { Vari. }}{\text { Stat. }}$} & \multicolumn{2}{|c|}{ Ske. } & \multicolumn{2}{|c|}{ Kurtosis } \\
\hline & & & & Stat. & Sd. E & & & Stat. & Sd. E & Stat. & Sd. E \\
\hline $\mathrm{SiO}_{2}$ & 8.5 & 15.5 & 24.0 & 19.9 & 0.9 & 2.8 & 8.0 & 0.1 & 0.7 & -1.0 & 1.3 \\
\hline $\mathrm{Cl}$ & 354.0 & 106.0 & 460.0 & 234.6 & 36.0 & 119.4 & 14259 & 1.1 & 0.7 & 0.2 & 1.3 \\
\hline $\mathrm{pH}$ & 0.3 & 8.1 & 8.4 & 8.3 & 0.0 & 0.1 & 0.0 & -0.6 & 0.8 & -0.3 & 1.5 \\
\hline EC & 1250.0 & 759.5 & 2009.5 & 1366.4 & 114.3 & 379.2 & 143804 & 0.4 & 0.7 & -0.5 & 1.3 \\
\hline TDS & 646.5 & 730.5 & 1377.0 & 973.5 & 79.0 & 236.9 & 56122 & 0.8 & 0.7 & -0.8 & 1.4 \\
\hline
\end{tabular}

Table 3. Pre-monsoon descriptive statistics

\begin{tabular}{|c|c|c|c|c|c|c|c|c|c|c|c|}
\hline \multirow{2}{*}{ Parameters } & \multirow{2}{*}{$\begin{array}{c}\text { Range } \\
\text { Stat. }\end{array}$} & \multirow{2}{*}{$\begin{array}{l}\text { Min. } \\
\text { Stat. }\end{array}$} & \multirow{2}{*}{$\begin{array}{l}\text { Max. } \\
\text { Stat. }\end{array}$} & \multicolumn{2}{|c|}{ Mean } & \multirow{2}{*}{$\frac{\text { Sd. D }}{\text { Stat. }}$} & \multirow{2}{*}{$\begin{array}{r}\text { Vari. } \\
\text { Stat. }\end{array}$} & \multicolumn{2}{|c|}{ Ske. } & \multicolumn{2}{|c|}{ Kurtosis } \\
\hline & & & & Stat. & Sd. E & & & Stat. & Sd. E & Stat. & Sd. E \\
\hline $\mathrm{SiO}_{2}$ & 11.0 & 10.5 & 21.5 & 16.7 & 1.2 & 3.5 & 12.3 & -0.3 & 0.7 & -0.4 & 1.4 \\
\hline $\mathrm{Cl}$ & 417.8 & 139.2 & 557.0 & 275.5 & 36.0 & 119.5 & 14279 & 1.3 & 0.7 & 2.2 & 1.3 \\
\hline $\mathrm{pH}$ & 0.8 & 8.0 & 8.8 & 8.4 & 0.1 & 0.2 & 0.1 & -0.1 & 0.7 & 0.2 & 1.3 \\
\hline EC & 962.5 & 1118 & 2080.5 & 1488.3 & 119.4 & 358.3 & 128384 & 0.8 & 0.7 & -0.9 & 1.4 \\
\hline TDS & 643.5 & 723.5 & 1367.0 & 963.5 & 69.0 & 235.9 & 56118 & 0.7 & 0.8 & -0.7 & 1.3 \\
\hline
\end{tabular}

\section{Correlation analysis}

Figures 5 (a to d) and 6 (a to d) show the correlation of $\mathrm{SiO}_{2}$ with respect to other selected groundwater parameters. $\mathrm{SiO}_{2}$ values have been related to $\mathrm{Cl}$ (Fig.5a),pH (Fig. 5b), EC (Fig. 5c) and TDS (Fig. 5d). On $\mathrm{SiO}_{2}-\mathrm{Cl}$ plot, samples Villivakkam, K.K. Nagar and Thirumangalam occupy a small cluster defined by higher $\mathrm{SiO}_{2}$ values of 19.5-20ppm and relatively high $\mathrm{Cl}$ values of $200-275 \mathrm{ppm}$. These monitoring locations suggest a normal $\mathrm{SiO}_{2}-\mathrm{Cl}$ relationship, suggesting a dominant role of water-rock interaction during premonsoon. Groundwater sample from Velachery is anomalously enriched in $\mathrm{Cl}$ probably due to seepage from highly contaminated surface water. $\mathrm{SiO}_{2}-\mathrm{TDS}$ plot (Fig. 5d) is nearly a curve (vertical) indicating that silica values have a good explicit relationship with TDS values and any TDS value of 900 to <1000ppm (Villivakkam, Chintadripet, Kotturpuram, Velachery and Thirumangalam) may be possible for nearly identical $\mathrm{SiO}_{2}$ concentration during pre- 
monsoon. If the bulk of solute acquisition (TDS) had resulted from water-rock interaction, a positive correlation between $\mathrm{SiO}_{2}$ and TDS would have been logically expected. Therefore, it may be inferred that relatively high concentration levels of TDS are related to anthropogenic rather than a geogenic phenomenon. Similarly, the trend is showing by the $\mathrm{SiO}_{2}-$ TDS plot during pre-monsoon (Figure. 6d). Generally, in the study area, groundwater $\mathrm{pH}$ is slightly alkaline in neutral in all location points, and it does not show any relation with $\mathrm{SiO}_{2}$ during pre-monsoon $\left(\mathrm{SiO}_{2}-\mathrm{pH}\right.$, Fig. 6b).

However, there was no good correlation found between $\mathrm{SiO} 2$ and other parameter's plots (Fig. 6 a, b, and c) except $\mathrm{SiO} 2-\mathrm{TDS}$ plot (Figure. 6d); this relationship reduces in comparison of pre-monsoon. This is maybe due to an insufficient increment in TDS concerning $\mathrm{SiO}_{2}$ in comparison to pre-monsoon.

\section{Correlation matrix analysis}

Correlation matrix Pearson (r), Kendall's (Nonparametric), and Spearman's (rho) analysis was conducted for post and pre-monsoon characterization using SPSS Software. Based on the SPSS output report, as a matrix table (Table 4a, b, c (Post-monsoon) and 5a, b, c (Premonsoon), and matrix image (Figure. $7 \mathrm{a}$ and $\mathrm{b}$ ) form, TDS and EC have a strong correlation of $0.99(\approx 1)$, at 0.01 level 2tailed during pre-monsoon also reveal from the figure (Fig. 7 b, Table 5a). Similarly, the correlation of $\mathrm{Cl}$ with EC (0.79, Table 5a) and TDS (0.79, Table 5a) is significant at the 0.05 level (2-tailed), while $\mathrm{Cl}$ and $\mathrm{pH}$ were negatively correlated (at 0.05 level) with -0.80 according to Pearson correlation matrix. From Kendall's correlation, $\mathrm{Cl}$ having a good correlation (0.71, Table 5b) with EC and TDS, while
Spearman's correlation also shows a good correlation but in an improved version (Table $5 c$ with EC and TDS at the 0.05 level (2-tailed).

In Table $4 \mathrm{a}, \mathrm{Cl}$ with EC (0.81, Figure. 7 a) shows an increasing trend in the compassion of pre-monsoon while the correlation between $\mathrm{Cl}$ and TDS decreases with the compassion of pre and a less negative correlation developed between $\mathrm{Cl}$ and $\mathrm{pH}$ during post-monsoon. Table $4 \mathrm{~b}$ (and Figure. 7 a) showed that $\mathrm{Cl}$ and EC had unchanged Kendall's correlation during post-monsoon. Meanwhile, a strong Kendall correlation was vanishing for $\mathrm{Cl}$ and TDS (Table $4 \mathrm{~b}$ ). Table $4 \mathrm{c}$ revealed that $\mathrm{Cl}$ correlated with EC (0.88) but not with TDS. Similarly, TDS correlated with EC but not $\mathrm{Cl}$ (Table 4c) during post-monsoon.

The EC generally is an indication of electrolyte in the dissolved constituents of the groundwater, while the high values of the EC $(1000 \mu \mathrm{S} / \mathrm{cm})$ in some of the locations may indicate sewage contamination in these areas (Rawat et al., $2018 a$ \&b; Gautam et al., 2015; Gautam et al., 2018). The TDS rich location indicates the presence of solutes and the dissolved constituents' mixing process in the groundwater. The variation in EC and TDS level in the sampled open borewells might have been occasioned by differential sedimentation along the water column in CGWB-C open borewells (Sobulo 1991; Bamgbose et al. 2001). In most locations, both the EC and TDS values are still within the permissible limit as 500 to $1000 \mu \mathrm{S} / \mathrm{cm}$ and 500 to $1400 \mathrm{ppm}$, respectively (WHO 1971, 1993). The measured value of silica in the groundwater implies that silica is one of the major chemical components of the water samples from the CGWB-C open borewells. These high values of dissolved silica with a range of 0.5 to 19.9 ppm must have been favored by both the high Si content
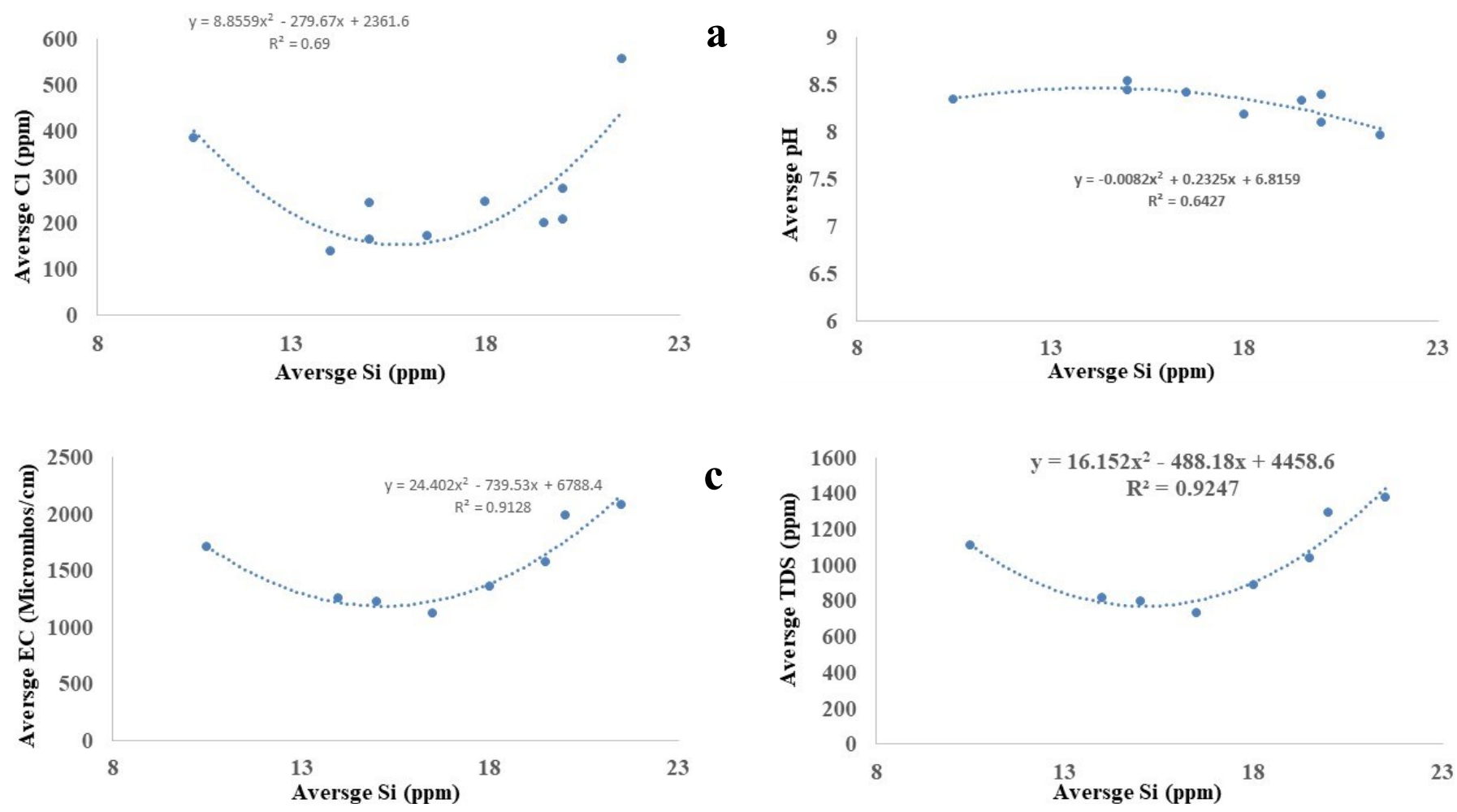

Figure 5. (a to d) Correlation-ship (during pre-monsoon) of $\mathrm{SiO}_{2}$ with other G.W. parameters 
Table 4.Correlation matrix for post-monsoon

\begin{tabular}{|c|c|c|c|c|c|}
\hline \multicolumn{6}{|c|}{$\mathrm{a}\left(\right.$ Pearson, $\left.\mathrm{r}_{\mathrm{p}}\right)$} \\
\hline & $\mathrm{SiO}_{2}$ & $\mathrm{Cl}$ & $\mathrm{pH}$ & $\mathrm{EC}$ & TDS \\
\hline $\mathrm{SiO}_{2}$ & 1 & 0.03 & .142 & 0.29 & -0.03 \\
\hline $\mathrm{Cl}$ & 0.03 & 1 & -0.44 & 0.81 & 0.51 \\
\hline $\mathrm{pH}$ & 0.14 & -0.44 & 1 & -0.23 & -0.28 \\
\hline $\mathrm{EC}$ & 0.29 & 0.81 & -0.23 & 1 & 0.69 \\
\hline TDS & -0.03 & 0.51 & -0.28 & 0.69 & 1 \\
\hline \multicolumn{6}{|c|}{$\mathrm{b}\left(\right.$ Kendall's, $\left.\mathrm{r}_{\mathrm{k}}\right)$} \\
\hline & $\mathrm{SiO}_{2}$ & $\mathrm{Cl}$ & $\mathrm{pH}$ & $\mathrm{EC}$ & TDS \\
\hline $\mathrm{SiO}_{2}$ & 1 & 0.04 & 0.25 & 0.18 & 0.04 \\
\hline $\mathrm{Cl}$ & 0.04 & 1 & 0.07 & 0.71 & 0.43 \\
\hline $\mathrm{pH}$ & 0.25 & 0.07 & 1 & -0.07 & -0.07 \\
\hline $\mathrm{EC}$ & 0.18 & 0.71 & -0.07 & 1 & 0.57 \\
\hline TDS & 0.04 & 0.43 & -0.07 & 0.57 & 1 \\
\hline \multicolumn{6}{|c|}{ c (Spearman's rho. $\left.r_{s}\right)$} \\
\hline & $\mathrm{SiO}_{2}$ & $\mathrm{Cl}$ & $\mathrm{pH}$ & $\mathrm{EC}$ & TDS \\
\hline $\mathrm{SiO}_{2}$ & 1 & 0.04 & 0.29 & 0.29 & -0.05 \\
\hline $\mathrm{Cl}$ & 0.04 & 1 & 0.02 & 0.88 & 0.59 \\
\hline $\mathrm{pH}$ & 0.23 & 0.02 & 1 & -0.07 & -0.21 \\
\hline $\mathrm{EC}$ & 0.29 & 0.88 & -.071 & 1 & 0.71 \\
\hline TDS & -0.05 & 0.59 & -0.21 & 0.71 & 1 \\
\hline
\end{tabular}

Table 5. Correlation matrix of pre-monsoon

\begin{tabular}{|c|c|c|c|c|c|}
\hline \multicolumn{6}{|c|}{$\mathrm{a}\left(\right.$ Pearson, $\left.\mathrm{r}_{\mathrm{p}}\right)$} \\
\hline & $\mathrm{SiO}_{2}$ & $\mathrm{Cl}$ & $\mathrm{pH}$ & $\mathrm{EC}$ & TDS \\
\hline $\mathrm{SiO}_{2}$ & 1 & 0.18 & -0.51 & 0.41 & 0.43 \\
\hline $\mathrm{Cl}$ & 0.18 & 1 & -0.80 & 0.79 & 0.79 \\
\hline $\mathrm{pH}$ & -0.51 & -0.80 & 1 & -0.54 & -0.56 \\
\hline $\mathrm{EC}$ & 0.41 & 0.79 & -0.54 & 1.00 & 0.99 \\
\hline TDS & 0.43 & 0.80 & -0.56 & 0.99 & 1 \\
\hline \multicolumn{6}{|c|}{$\mathrm{b}\left(\right.$ Kendall's, $\left.\mathrm{r}_{\mathrm{k}}\right)$} \\
\hline & $\mathrm{SiO}_{2}$ & $\mathrm{Cl}$ & $\mathrm{pH}$ & $\mathrm{EC}$ & TDS \\
\hline $\mathrm{SiO}_{2}$ & 1 & 0.43 & -0.43 & 0.52 & 0.52 \\
\hline $\mathrm{Cl}$ & 0.43 & 1 & -0.62 & 0.71 & 0.71 \\
\hline $\mathrm{pH}$ & -0.43 & -0.62 & 1 & -0.33 & -0.33 \\
\hline $\mathrm{EC}$ & 0.52 & 0.71 & -0.33 & 1 & 1 \\
\hline TDS & 0.52 & 0.71 & -0.33 & 1 & 1 \\
\hline \multicolumn{6}{|c|}{ c (Spearman's rho. $\left.r_{s}\right)$} \\
\hline & $\mathrm{SiO}_{2}$ & $\mathrm{Cl}$ & $\mathrm{pH}$ & $\mathrm{EC}$ & TDS \\
\hline $\mathrm{SiO}_{2}$ & 1 & 0.43 & -0.57 & 0.61 & 0.61 \\
\hline $\mathrm{Cl}$ & 0.43 & 1 & -0.71 & 0.89 & 0.89 \\
\hline $\mathrm{pH}$ & -0.57 & -0.71 & 1 & -0.61 & -0.61 \\
\hline $\mathrm{EC}$ & 0.61 & 0.89 & -0.61 & 1 & 1 \\
\hline TDS & 0.61 & 0.89 & -0.61 & 1 & 1 \\
\hline
\end{tabular}



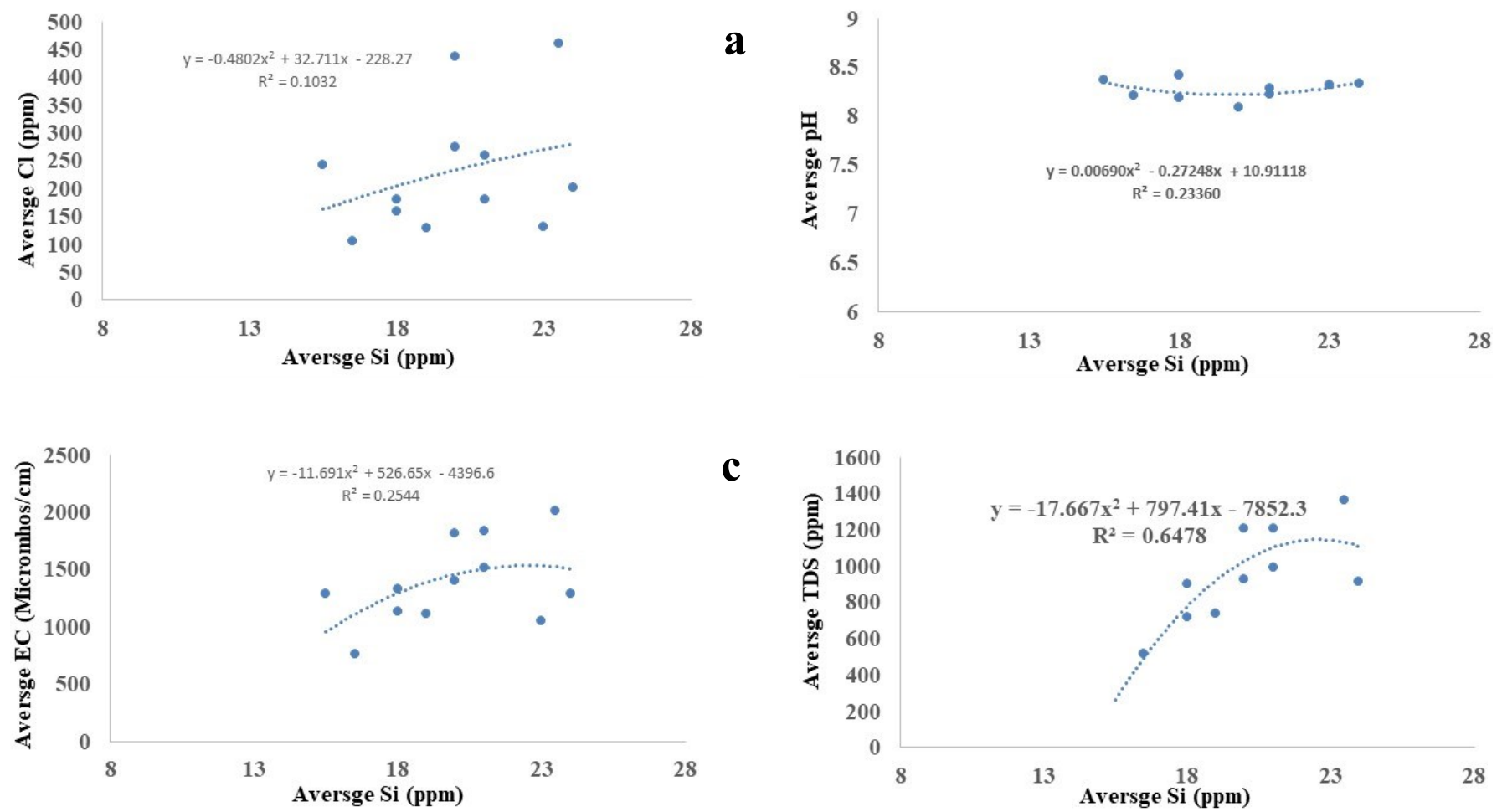

Figure 6. (a to d). Correlation-ship (during post-monsoon) of $\mathrm{SiO}_{2}$ with other groundwater parameters
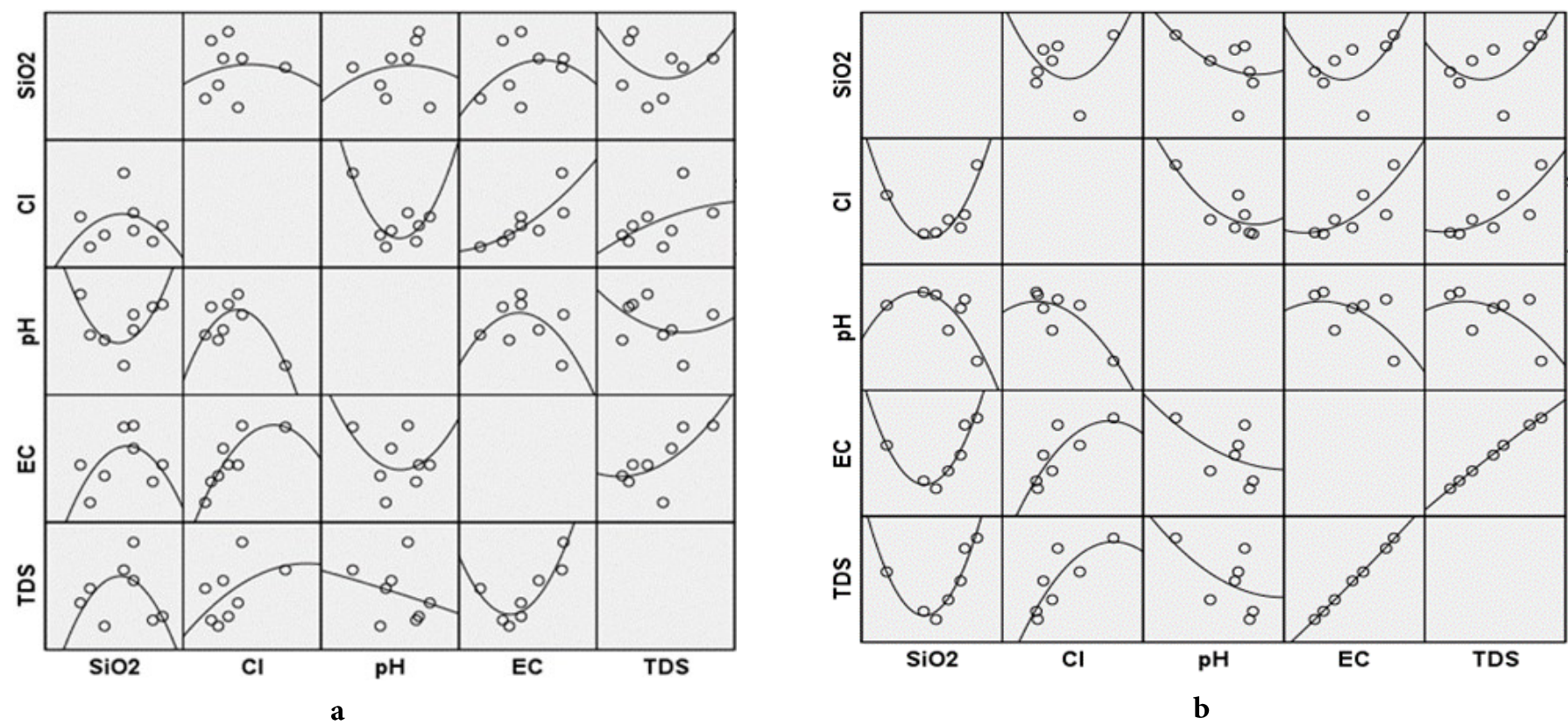

Figure7. (a) Post-monsoon and (b) Pre-monsoon correlation matrix

of the host parent rocks and the high degree of weathering that characterizes the peninsular regions. As a result of the favorable climatic conditions (high temperature and rainfall) in the peninsular regions, the silicate minerals are easily weathered, thereby releasing more of the crystalline silica $\left(\mathrm{SiO}_{2}\right)$ in solution.

Based on NEST (1991) suggestion, more rainwater harvesting/stored underground than is available on the surface (this policy is applicable or adopted in our study area). This fact may be the reason why the groundwater in the study area had more Si loads. A high value of Si in the study area's groundwater may be due to existing rocks and a high degree of interaction with groundwater that characterizes these regions. The observed minimum levels of $\mathrm{Si}$ in the CGWB-C open borewells from the study area indicate that the source of the Si element in groundwater is more of chemical weathering of the existing/host rock than anthropogenic phenomenon (Iler, 1979). As a study by Hem (1970), weathering of silicate minerals is one of the most important causes of high Si concentrations in groundwater. The Si element in groundwater may be partly from the weathered profile of the basement complex rocks, which have been found to be rich in mineral concentration (Palacky and Kadekaru 1979). The correlation analysis in Table 4 (a, b, c) and $5(\mathrm{a}, \mathrm{b}, \mathrm{c})$ shows that a non-significant positive and weak negative correlation was established between $\mathrm{Si}$ and 
$\mathrm{pH}$. The bivariate plots depicted in Figure 5 (a to d) further confirms the weak associations between Si load of the CGWB -C open borewells, and $\mathrm{Cl}, \mathrm{pH}, \& \mathrm{EC}$ during post-monsoon. Perhaps the level of $\mathrm{Si}$ is negligible in water to cause any illness.

\section{Conclusion}

$\mathrm{Si}$ values, when related to a rather conservative ion $\mathrm{Cl}$ or total solute concentration, may provide valuable information that can help identify the source of chemical species and play a significant role in managing and conserving precious groundwater resources. It is therefore strongly recommended that silica determinations should be taken up in all groundwater investigations. Though the health implications of dissolved Si in drinking water are yet to be documented, the Si standard in drinking water should be established by the appropriate environmental agencies in various countries. This will assist in the close monitoring of silica load in the water resources of the tropical regions characterized by intensive weathering.

\section{Acknowledgment}

The authors wish to acknowledge Dr. A.K. Mishra, Principal Scientist, Water technology Center, IARI New Delhi, and Mr. K. Santhanam, Ex. Deputy Director, PWD Groundwater, Chennai, for the support rendered for the work's successful completion. "This research is not received any financial support from any funding agencies".

\section{References}

Bamgbose,O.,Arowolo, T.A.,\&O. Odukoya,2009:Comparison of drinking water quality in Abeokuta Township with WHO standards.Water Res,12,37-44.

Chehata, M., Jasinski, D., Monteith, M.C.,\&W.B. Samuels 2007:Mapping three-dimensional water-quality data in the Chesapeake Bay using geostatistics.J Am Water Resour Assoc., 43/3, 813-828.doi:http://dx.doi.org/10.1111/j.17521688.2007.00065.x

Dobbie,J.W.,\&M.J. Smith1982:Silicate nephrotoxicity in the experimental animal: the missing factor in analgesic nephropathy. Scott Med J. 27/1,10-6.

Fournier, R.O.1983:A revised and expanded silica geothermometer.Bull. Geotherm. Res. Council, 11:329.

Ghahramani, N.2010:Silica nephropathy.IntJ Occup Environ Med,1/3,108-115.

Giggenbach, W.F., Gonfiantini, R., Jangi, B.L.,\&A.H. Truesdell 1985:Isotopic and chemical composition of Parbati valley geothermal discharges, Northwest Himalaya India. Geothermics,12,199-222.

Gautam, S. K., Tripathi, J. K., \& Singh, S. K. (2020). Assessing the suitability of Ghaghra River water for irrigation purpose in India. Agricultural Water Management: Theories and Practices, 12, 67.

Gautam, S. K., Maharana, C., Sharma, D., Singh, A. K., Tripathi, J. K., \& Singh, S. K. (2015). Evaluation of groundwater quality in the Chotanagpur plateau region of the Subarnarekha river basin, Jharkhand State, India. Sustainability of Water Quality and Ecology, 6, 57-74.

Gautam, S. K., Evangelos, T., Singh, S. K., Tripathi, J. K., \& Singh, A. K. (2018). Environmental monitoring of water resources with the use of PoS index: a case study from Subarnarekha River basin, India. Environmental earth sciences, 77(3), 70.

Hauglustaine, D.,Van Damme,B., Daenens, P.,\&P. Michielsen1980:Silicon nephropathy, a possible occupational hazard.Nephron,26/5:219-24.

J.D. Hem1970.Study and Interpretation of the Chemical
Characteristics of Natural Waters. Excellent Reviews of the Chemistry of Natural Water and of the Significance of Properties and Constituents Reported in Water Analyses. $2^{\text {nd }}$ Edition. U.S. Geol. Survey. Water Supply Paper No. 1473: P. 363.

J.D. Hem 1985:Study and Interpretation of the Chemical Characteristics of Natural Water. 3rd Edition. U.S. Geological Survey Water-Supply Paper 2254:P. 263.

Iler,R.K. 1979:The Chemistry of Silica: Solubility, Polymerization, Colloid and Surface Properties and Biochemistry.John Wiley and Sons. New York.

Jacintha T.G.A., Rawat, K.S., Mishra, A.,\&S.K. Singh2016:Hydrogeochemical Characterization of Groundwater of Penninsular Indian Region using Multivariate Statistical Techniques.Appl Water Sci,7/6, 30013013

Jansen, N.,\& Hartmann, J., Lauerwald,R., Durr, H.H., Kempe, S., Loos, S.,\&H Middelkoop2010:Dissolved silica mobilization in the conterminous USA.Chem Geol, 270, 90-109.

Nemčić-Jurec, J., Singh, S. K., Jazbec, A., Gautam, S. K., \& Kovač, I. (2019). Hydrochemical investigations of groundwater quality for drinking and irrigational purposes: two case studies of Koprivnica-Križevci County (Croatia) and district Allahabad (India). Sustainable Water Resources Management, 5(2), 467490.

Lopez-Granados, F., Jurado-Expósito, M., Peña-Barragán, J.M.,\&L. García-Torres2005:Using geostatistical and remote sensing approaches for mapping soil properties.Eur. J. Agron,23/3, 279-289. doi:http://dx.doi.org/10.1016/j.eja.2004.12.003

Maliqi, E., Jusufi, K., \& Singh, S. K. (2020). Assessment and Spatial Mapping of Groundwater Quality Parameters Using Metal Pollution Indices, Graphical Methods and Geoinformatics. Analytical Chemistry Letters, 10(2), 152-180.

Marchand,D., Rayan, C., Bethune, D.N.,\&Chu, A. (2002). Groundwater-Surface Water Interaction and Nitrate Oriin in Municipal Water Supply Aquifers, Sanjose. Costa.Rica.

Moharir, K., Pande, C., Singh, S. K., Choudhari, P., Kishan, R., \& Jeyakumar, L. (2019). Spatial interpolation approach-based appraisal of groundwater quality of arid regions. Journal of Water Supply: Research and Technology-AQUA, 68(6), 431447.

Nigerian Environmental Study Team (NEST). Nigeria's Threatened Environment: A National Profile Ibadan. (1991).NEST Publication, P 45.

Nour, M.H., Smit, D.W.,\&M.G. EL-Din2006:Geostatistical mapping of precipitation Implication for rain gauge network design.Water. Sci Technol,53/10,101-110.

Osorio,A.M., Thun,M.J., Novak, R.F., Van Cura, E.J.,\&E.D. Avner1987:Silica and glomerulonephritis: case report and review of the literature.Am J Kidney Dis.9/3,224-30.

Palacky, G.J.,\&K. Kadekaru1979:Effect of tropical weathering on electrical and electromagnetic measurements.Geophysics, 44/1:59-68.

Rawat,K.S., Jacintha, T.G.A., Singh, S.K., Nemčić-Jurec J.,\&V.K. Tripathi2017:Appraisal of Long Term Groundwater Quality of Peninsular India using Water Quality Index and Fractal Dimension. J. Earth Syst, 126/8, 126:122.

Rawat, K.S., Mishra, A.K.,\&S.K. Singh2017:Mapping of Groundwater Quality Using Normalized Difference Dispersal Index of Dwarka Sub-city at Delhi National Capital of India.ISH JHydraEngi,23/3,229-240.

Rawat,K.S.,Singh,S.K. \& S. Guatam 2018:Assessment of groundwater quality for irrigation use: a Peninsular case study.ApplWater Sci.,8:233.1-24.

Rawat, K.S.,\&S.K. Singh,2018:Water Quality Indices and GIS-based evaluation of a decadal groundwater quality. Geology Ecology and Landscapes, 2/4, 240-255

Moharir, K, Pande, C., Singh, S.K., Choudhari, P.P.,Rawat, K.S,\&L. Jeyakumar 2019:Spatial interpolation approach-based 
appraisal of groundwater quality of arid regions. Journal of Water Supply: Research and Technology - AQUA, 68 (6), 431 $-447$

Rawat, K.S., Tripathi, V.K.,\&S.K. Singh2018a:Groundwater Quality Evaluation using Numerical Indices: a case study (Delhi, India).Sustainable Water Resources Management, 4, 875-885. doi:10.1007/s40899-017-0181-9.

Rawat KS., Jacintha TGA.,\& S.K. Singh 2018b:Hydro-chemical Survey and Quantifying Spatial Variations in Groundwater Quality in Coastal Region of Chennai, Tamilnadu, India - a case study. Indonesian Journal of Geography, 50 (1), 57 - 69.

Rawat, K.S.,\&S.K. Singh2018c:An integrated framework for identification of polluted zones: a study from coastal aquifer of India. Indonesian Journal of Geography, 51(1), 78-87.

Rawat KS., Singh SK., Jacintha TGA., Nemc`ic'-Jurec J.,\&V.K.Tripathi 2018d: Appraisal of long term groundwater quality of peninsular India using water quality index and fractal dimension. J. Earth Syst. Sci. 126:122, 1-24.https:// doi.org/10.1007/s12040-017-0895-y

Rawat, K.S., Jeyakumar, L., Singh, S.K.,\&V.K. Tripathi2019:Appraisal of Groundwater with Special Reference to Nitrate Using Statistical Index Approach. Groundwater for Sustainable Development,8, 49-58.

Rawat, K.S., Pradhan, S., Tripathi, V.K., Lordwin, J.,\&S.K. Singh 2019b:An application of Water Quality Index (WQI) and statistical approaches to evaluate the Groundwater Contamination for drinking and irrigation purposes. Groundwater for Sustainable Development,9, 1-12.

Saravanan, J., Rawat, K.S.,\&S.K. Singh 2018: Groundwater quality of coastal aquifer evaluation using spatial analysis approach.Oriental Journal of Chemistry,34(6), 2902-2912

Saravanan,J., Rawat,K.S.,\&S.K. Singh2018:Study of Sub Surface Hydrogeology of Chennai Metropolitan Area.Current World Environ, 13(3), 317-330.

Sauquet, E.(2006). Mapping mean annual river discharge: Geostatistical development for incorporating river network dependencies.J Hydrol, 331/1-2, 300-314.

Sobulo, T.O.(1919). Survey of water supply and disposal system in Abeokuta with suggestions.Nig J Sci,21:10-15.
Singh, S. K., Srivastava, P. K., Singh, D., Han, D., Gautam, S. K., \& Pandey, A. C. (2015). Modeling groundwater quality over a humid subtropical region using numerical indices, earth observation datasets, and X-ray diffraction technique: a case study of Allahabad district, India. Environmental geochemistry and health, 37(1), 157-180.

Singh, S. K., Srivastava, P. K., Pandey, A. C., \& Gautam, S. K. (2013). Integrated assessment of groundwater influenced by a confluence river system: concurrence with remote sensing and geochemical modelling. Water resources management, 27(12), 4291-4313.

Singh, S. K., Singh, P., \& Gautam, S. K. (2016). Appraisal of urban lake water quality through numerical index, multivariate statistics and earth observation data sets. International journal of environmental science and technology, 13(2), 445-456.

Stratta,P., Canavese, C., Messuerotti,A., Fenoglio, I.,\&Fubini, B. (2001). Silica and renal diseases: no longer a problem in the 21st century.J. Nephrol.14/4, 228-247.

Swanberg, C.A.,\&P. Morgan1978:The linear relation between temperatures based on the silica content of groundwater and regional heatflow: a new heat flow map of the United State.J Pure Appl Geophys, 117, 1-12.

Todd, M.J., Lowrance, R.R., Goovaerts, P., Vellidis, G.,\&C.M. Pringle2010:Geostatistical modeling of the spatial distribution of sediment oxygen demand within a Coastal Plain backwater watershed.Geoderma, 159/1-2,53-62.

Wackernagel, H., Lajaunie, C., Blond, N., Roth, C.,\&R. Vautard2004:Geostatistical risk mapping with chemical transport model output and ozone station data.Ecol. Modell, 179/2, 177-185.

World Health Organization (WHO)2006:Safe Water and Global Health, From<www.who/int/features/qa/ 70/en/index.htm. (Retrieved on 12 May 2011).

Yousafzai, A., Eckstein, Y.,\&P.S. Dahal2010:Hydrochemical signatures of deep groundwater circulation in a part of the Himalayan foreland basin.Environ Earth Sci,59, 1079-1098. 